\title{
Inhibition of Prostaglandin Synthesis after Metabolism of Menadione by Cultured Porcine Endothelial Cells
}

\author{
Aaron Barchowsky, Katayoun Tabrizi, Richard S. Kent, * and A. Richard Whorton \\ Divisions of Pulmonary Medicine and Cardiology, ${ }^{*}$ Departments of Pharmacology and Medicine, \\ Duke University Medical Center, Durham, North Carolina 27710
}

\begin{abstract}
We have examined the effects of menadione on porcine aortic endothelial cell prostaglandin synthesis. Addition of 1-20 $\mu \mathrm{M}$ menadione caused a dose- and time-dependent inhibition of stimulated prostaglandin synthesis with an $\mathrm{IC}_{50}$ of $5 \mu \mathrm{M}$ at 15 min. Concentrations greater than $100 \mu \mathrm{M}$ menadione were necessary to increase ${ }^{51} \mathrm{Cr}$ release from prelabeled cells. Recovery of enzyme inactivated by menadione required a 6-h incubation in $1 \%$ serum. In a microsomal preparation, menadione was shown to have no direct effect on conversion of arachidonic acid to prostaglandins. In intact cells menadione caused only a $40 \%$ inhibition of the conversion of $\mathbf{P G H}_{2}$ to prostacyclin. Enzymes involved in the incorporation and the release of arachidonic acid were not affected by menadione ( $20 \mu \mathrm{M}, 15 \mathrm{~min})$. Menadione undergoes oxidation/reduction reactions in intact cells leading to partial reduction of oxygen-forming, reactive oxygen species. In our cells menadione was found to increase KCN-resistant oxygen consumption. Further, an increased accumulation of $\mathrm{H}_{2} \mathrm{O}_{2}$ was observed with a time course consistent with menadione-induced inhibition of prostaglandin synthesis. We conclude that menadione at sublethal doses caused inhibition of prostaglandin synthesis. The mechanism involves inactivation of $\mathbf{P G H}_{2}$ synthase by a reactive species resulting from metabolism of menadione by endothelial cells.
\end{abstract}

\section{Introduction}

Numerous studies have shown that damage to vascular endothelium is a primary event in oxidative injury caused by hyperoxia (1-3), hypoxia (4), activated neutrophils (1,5), endotoxin $(6,7)$, or certain chemotherapeutic agents $(8,9)$. In these studies, cytotoxicity was demonstrated by measuring gross morphologic changes (4, 7-9), by demonstrating loss of endothelial-dependent organ function (8), or by assessing loss of cell viability $(1,5,8)$. Comparatively few studies have addressed the effects of sublethal concentrations of oxidants or oxidantgenerating species on biological functions of the endothelial cell. One important endothelial function which has recently been demonstrated to be inhibited after exposure to sublethal

Portions of this work were presented in abstract form (1988. FASEB [Fed. Am. Soc. Exp. Biol.] J. 2:A1188).

Address reprint requests to Dr. Barchowsky at his present address: Division of Clinical Pharmacology, Thomas Jefferson University, 1100 Walnut Street, Philadelphia, PA 19107.

Received for publication 5 July 1988 and in revised form 27 September 1988.

J. Clin. Invest.

(c) The American Society for Clinical Investigation, Inc.

0021-9738/89/04/1153/07 $\$ 2.00$

Volume 83, April 1989, 1153-1159 concentrations of $\mathrm{H}_{2} \mathrm{O}_{2}$ and superoxide anion $\left(\mathrm{O}_{2}^{-}\right)$is the capacity of these cells to produce prostacyclin $\left(\mathrm{PGI}_{2} ; 10,11\right)$. It is well known that $\mathrm{PGI}_{2}$ synthesized by the endothelium plays a role in maintaining local blood flow $(12,13)$, in protecting against vascular injury by limiting the activation and adherence of neutrophils and platelets (12-15), and perhaps in modulating release of catecholamines (13). Thus, loss of the ability to produce $\mathrm{PGI}_{2}$ after oxidative stress may have profound implications on the role of the endothelium in maintaining vascular homeostasis.

The conversion of arachidonic acid to prostaglandins is known to be tightly regulated by oxidants, especially at the level of $\mathrm{PGH}_{2}$ synthase. In fact, the activity of this enzyme becomes rate limiting when the enzyme is fully reduced (a lack of oxidants) or when the enzyme metabolizes a sufficient concentration of hydroperoxide to cause autoinactivation $(16,17)$. In isolated systems, low levels of exogenous hydroperoxides have been shown to activate $\mathrm{PGH}_{2}$ synthase by reducing the lag time for arachidonic acid metabolism $(16,17)$. The regulatory mechanisms in intact cells are not completely understood. However, it has been shown that, in intact vessels (18) and in cultured endothelial cells, $\mathrm{PGH}_{2}$ synthase is irreversibly inactivated through autoinhibition (19) or after metabolism of exogenous hydroperoxides $(10,11,20)$. Recovery of inactivated prostaglandin synthetic capacity in these cells requires new enzyme synthesis (11).

Damaging concentrations of reactive oxygen species arise after metabolism of certain compounds by endothelial cells. Quinones represent an important group of such compounds, whose therapeutic effectiveness is limited by their ability to cause oxidative injury $(8,21,22)$. Quinone-induced toxicity has been observed in many organs and cell types and is thought to result from univalent reduction of the quinone to form the semiquinone radical (21-24). This reduction is catalyzed by flavin-containing, $\mathrm{NAD}(\mathrm{P}) \mathrm{H}$-dependent enzymes in the microsomal and mitochondrial fractions of the cell (21-24). Oxidation of the semiquinone in the presence of molecular oxygen regenerates the quinone and causes the formation of $\mathrm{O}_{2}^{-} \cdot \mathrm{O}_{2}^{-}$quickly dismutates to yield $\mathrm{H}_{2} \mathrm{O}_{2}(21-24)$ which may affect cell function. High doses of menadione (vitamin $\mathrm{K}_{3}$ ) have been shown to cause the production of $\mathrm{O}_{2}^{-}$and other reactive oxygen species in endothelial cells (25) and to alter cell membrane integrity. The effects of lower concentrations of quinones, which would presumably cause a lower level of intracellular oxidant production, on endothelial cell integrity and function have not been characterized.

Therefore, we chose to examine the effects of sublethal concentrations of menadione on prostaglandin production in endothelial cells. The concentration- and time-dependent effects of menadione on synthesis of $\mathrm{PGI}_{2}$ and prostaglandin $\mathrm{E}_{2}$ $\left(\mathrm{PGE}_{2}\right)$ were investigated and the activities of the enzymes in the synthetic cascade were determined to establish the site of 
action of menadione. In addition, the time course and dose dependence of the cytotoxic effects of menadione were evaluated and the requirements for recovery from menadione-induced effects were examined. The data presented demonstrate that low concentrations of menadione irreversibly inhibit endothelial prostaglandin synthesis. This inhibition appears to result from increased intracellular production of $\mathrm{H}_{2} \mathrm{O}_{2}$.

\section{Methods}

Materials. Menadione, arachidonic acid, bradykinin triacetate, catalase, superoxide dismutase, ibuprofen, and cytodex beads were obtained from Sigma Chemical Co. (St. Louis, MO). The calcium ionophore, A23187, was obtained as the free acid from Calbiochem-Behring Corp. (San Diego, CA). Dulbecco's modified Eagle's media (DME), Hanks' balanced salt solution (HBSS), medium 199, and other tissue culture reagents were obtained from Gibco (Grand Island, NY). Fetal calf serum (FCS) was obtained from HyClone Laboratories (Logan, UT). Deuterated prostaglandins, $\left[3,3,4,4,{ }^{2} \mathrm{H}\right] 6$-keto-prostaglandin $\mathrm{F}_{1 \mathrm{l}}$ and $\left[3,3,4,4,-{ }^{2} \mathrm{H}\right]$ prostaglandin $\mathrm{E}_{2}$ were purchased from Merck, Sharp \& Dohme (Montreal, Quebec). [5,6,8,9,11,12,14,15- $\left.{ }^{3} \mathrm{H}\right]$ arachidonic acid $(60 \mathrm{Ci} / \mathrm{mmol})$ and $\left[{ }^{5 i} \mathrm{Cr}\right] \mathrm{Na}_{2} \mathrm{CrO}_{4}(200 \mathrm{Ci} / \mathrm{g})$ were purchased from NEN Research Products (Boston, MA). All solvents were HPLC grade or of the highest purity available.

Cell culture. Endothelial cells were enzymatically isolated from fresh porcine aortas as previously described $(10,11)$ and cultured according to established methods $(10,11)$. The cells were grown in 25- $\mathrm{cm}^{2}$ flasks (NUNC, USA Plastics, Ocala, FL) containing DME plus $10 \% \mathrm{FCS}$ and were maintained at $37^{\circ} \mathrm{C}$ under an atmosphere of $10 \%$ $\mathrm{CO}_{2} / 90 \%$ air. The cells were subcultured using $0.1 \%$ trypsin-EDTA and confluent monolayers of second to fourth-passage cells were used for experimentation. The endothelial cells were characterized as previously reported $(11,26)$ with more than $90-95 \%$ of the cells in random cultures containing factor VIII antigen.

Culture of cells on cytodex 1 beads was essentially as described above. After isolation, cells were plated in $25-\mathrm{cm}^{2}$ flasks and allowed to grow to confluence. After demonstrating the purity of the culture, an aliquot of beads was added and the cells were cultured for an additional $2 \mathrm{~d}$. The beads were removed by gentle agitation and added to a stirred flask containing complete media plus $3 \mathrm{mg} / \mathrm{ml}$ fresh beads. Half of the media was exchanged every $3 \mathrm{~d}$ and cell numbers were increased by adding more media and beads.

Exposure to menadione. Endothelial cells were washed twice with Hepes-buffered HBSS (HHBS), ${ }^{1} \mathrm{pH} 7.4$, to remove the culture medium which contained serum. Menadione, dissolved in DMSO and diluted in HHBS, was added, incubated with the cells for the desired time period, and removed by another two rinses. The final concentration of DMSO was $<0.5 \%$ and an equal amount was added to controls. The capacity of the endothelial monolayers to produce prostaglandins was evaluated by addition of the sodium salt of arachidonic acid $(20 \mu \mathrm{M})$ dissolved in HHBS and incubated at $37^{\circ} \mathrm{C}$ for $3 \mathrm{~min}$. The buffer was collected, deuterated internal standards were added, and the samples were stored at $-20^{\circ} \mathrm{C}$ until analysis.

Prostaglandin analysis. Prostaglandin levels were determined according to previously published procedures by selective ion monitoring using a gas chromatograph-mass spectrometer equipped with an electron impact source $(10,11,18)$. Briefly, the samples were acidified with formic acid (pH 3.0) and extracted twice with 2 vol of ethyl acetate. After forming the methyl ester-methoxime-trimethylsilyl ether derivatives, the samples were injected on to a 6-ft $\times 4$-mm glass column packed with 3\% OV-1 on 80-100 Supelcoport (Supelco Inc., Bellefonte, PA) at a carrier gas flow of $25 \mathrm{ml} / \mathrm{min}$ and an oven temperature of $245^{\circ} \mathrm{C}$. These column conditions allowed complete baseline resolu-

1. Abbreviations used in this paper: HHBS, Hepes-buffered Hanks' balanced salt solution. tion of the derivatives of 6-keto-prostaglandin $F_{1, x}$ (the stable nonenzymatic metabolite of $\mathrm{PGI}_{2}$ ) and of $\mathrm{PGE}_{2}$.

Assay for cytotoxicity. The cytotoxic effect of menadione was examined by following ${ }^{51} \mathrm{Cr}$ release from cells prelabeled for $5 \mathrm{~h}$ with $\left[{ }^{51} \mathrm{Cr}\right] \mathrm{Na}_{2} \mathrm{CrO}_{4}(10 \mu \mathrm{Ci} /$ flask $)$. The cells were washed twice with HHBS containing $1.0 \%$ bovine serum albumin (BSA) and incubated for 10 min before two additional rinses. Menadione or $\mathrm{H}_{2} \mathrm{O}_{2}$ was then added in HHBS plus $1.0 \%$ BSA and aliquots of the incubation buffer were sampled for radioactivity at 30,60 , and $90 \mathrm{~min}$. Data are expressed as the percent of total releasable ${ }^{51} \mathrm{Cr}$.

Assay of microsomal PGH, synthase. Microsomes were prepared from ram seminal vesicles (Wayne State University, Detroit, MI) and resuspended $(10 \mathrm{mg} / \mathrm{ml})$ in $0.1 \mathrm{M}$ potassium phosphate buffer, $\mathrm{pH} 7.4$, containing $1 \mathrm{mM}$ EDTA. The microsomes were preincubated for 5 min at $37^{\circ} \mathrm{C}$ in buffer containing hemoglobin $(0.1 \mathrm{mg} / \mathrm{ml})$, phenol $(2$ $\mathrm{mM})$, and tryptophan $(1 \mathrm{mM})$ before addition of saturating levels of tritiated arachidonic acid $(100 \mu \mathrm{g} / \mathrm{ml}$ arachidonic acid plus $1.0 \mu \mathrm{Ci}$ $\left[{ }^{3} \mathrm{H}\right]$ arachidonic acid) for $2 \mathrm{~min}$. The reaction was stopped by addition of methanol-formic acid $(5: 2 \mathrm{vol} / \mathrm{vol})$. The incubation mixtures were extracted twice with ethyl acetate $(2 \mathrm{vol})$ and the organic layers were combined, evaporated, and redissolved in $5 \mathrm{ml}$ of hexane-diethyl ether (9:1). The samples were applied to a $0.75-\mathrm{g}$ silicic acid column, and unreacted arachidonic acid was eluted with $20 \mathrm{ml}$ of the same solvent. The sample vial was rinsed with and hydroxylated products were eluted with $20 \mathrm{ml}$ of hexane-ether (8:2). The sample vial was finally rinsed with and prostaglandins were eluted with ethyl acetate-methanol (9:1). Greater than $80 \%$ of the initial ${ }^{3} \mathrm{H}$ added was recovered, with $10-15 \%$ being lost to formation of $\left[{ }^{3} \mathrm{H}_{3} \mathrm{H}_{2} \mathrm{O}\right.$. Labeled prostaglandins, 15-hydroxyeicosatetranoic acid, and arachidonic acid were used to standardize the chromatography.

Release of arachidonic acid. To examine the effects of menadione on the release of arachidonic acid from endothelial cells, monolayers were incubated overnight in DME containing $1.0 \% \mathrm{FCS}$ and $2 \mu \mathrm{Ci}\left[{ }^{3} \mathrm{H}\right]$ arachidonic acid. The culture medium was removed by two washes with HHBS containing $0.25 \%$ BSA and the cells were exposed to menadione for $15 \mathrm{~min}$. The flasks were rinsed with three buffer washes and release of label was followed by sampling an aliquot of the buffer every $5 \mathrm{~min}$. After establishing basal release, either bradykinin $(1.0 \mu \mathrm{g} / \mathrm{ml})$ or A23187 $(1.0 \mu \mathrm{M})$ was added to stimulate arachidonic acid release. Radioactivity was quantified by liquid scintillation counting.

Oxygen uptake assay. Oxygen consumption by endothelial cells grown on cytodex beads was measured at $37^{\circ} \mathrm{C}$ using a Clark electrode fitted into a stirred chamber. The change in electrode potential was monitored with an oxygen monitor (Yellow Springs Instruments, Yellow Springs, $\mathrm{OH}$ ) with output to a strip chart recorder. The electrode was calibrated using air equilibrated HHBS. An aliquot of beads was added to the chamber in the same buffer and data obtained from different experiments were normalized for protein content of the aliquot.

Measurement of $\mathrm{H}_{2} \mathrm{O}_{2}$. To measure formation of $\mathrm{H}_{2} \mathrm{O}_{2}$ after addition of menadione, monolayers of cells were rinsed and incubated for $15 \mathrm{~min}$ with $2 \mathrm{ml}$ of HHBS containing menadione. Separate groups of flasks were treated similarly with buffer containing $1 \mathrm{mM} \mathrm{NaN}_{3}$. After the exposure period, the buffer was removed and assayed for $\mathrm{H}_{2} \mathrm{O}_{2}$ content using the colorimetric assay described by Thurman et al. (27). $\mathrm{NaN}_{3}$ did not alter the assay results. Specificity of the procedure was determined by quantifying $\mathrm{H}_{2} \mathrm{O}_{2}$ in aliquots of buffer treated with $10 \mathrm{U}$ of catalase. All values were compared to production in nontreated cells.

Enzyme assays. Catalase activity was assayed by determining the rate of $\mathrm{H}_{2} \mathrm{O}_{2}$ reduction (decrease in absorbance at $280 \mathrm{~nm}$ ) as described by Bergmeyer (28). Superoxide dismutase activity was determined by the ability to prevent reduction of acetylated cytochrome $\mathrm{c}$ as described by McCord and Fridovich (29).

Statistics. To test for significant differences, data were analyzed by analysis of variance following Bartlett's test for normal distribution. When necessary, log transforms were made to normalize the variance. The means of groups were compared using Student-Newman-Keuls or 
Dunnett's tests. Data are presented as mean \pm standard deviation unless designated otherwise.

\section{Results}

We have previously demonstrated that addition of $20 \mu \mathrm{M}$ arachidonic acid to confluent monolayers of porcine aortic endothelial cells for $3 \mathrm{~min}$ results in maximal production of prostaglandins (11). The primary prostaglandin produced by these cells is $\mathrm{PGI}_{2}$, with a minor amount of $\mathrm{PGE}_{2}$ also being formed $(10,11,26)$. Pretreatment of the cells for 10,15 , or $30 \mathrm{~min}$ with varying concentrations of menadione caused a time- and concentration-dependent inhibition of prostaglandin synthesis (Fig. 1) with an $\mathrm{IC}_{50}=5 \mu \mathrm{M}$ at $15 \mathrm{~min}$. Although the data presented represent only the production of $\mathrm{PGI}_{2}$, the synthesis of $\mathrm{PGE}_{2}$ decreased in a parallel fashion $(76.9 \pm 13.1 \%$ inhibition after 15 -min treatment with $20 \mu \mathrm{M}$ menadione, $n=9$ ). Exposure of monolayers to higher concentrations of menadione also inhibited basal prostaglandin production as indicated by a $>100 \%$ inhibition of the capacity to convert exogenous arachidonic acid.

Since menadione was found to affect the function of endothelial cells, we chose to examine the cytotoxicity of the compound. Cytotoxicity was measured by determining the rate of ${ }^{51} \mathrm{Cr}$ release from prelabeled cells exposed to increasing concentrations of menadione. There was no increase in release of ${ }^{51} \mathrm{Cr}$ above control values at concentrations of menadione that maximally inhibit prostaglandin synthesis. However, when cells were exposed to much larger doses of menadione ( $1 \mathrm{mM})$, there was a significant increase in ${ }^{51} \mathrm{Cr}$ release $60 \mathrm{~min}$ after addition of the drug (Fig. 2). This effect on membrane integrity occurred at a dose that is 200 -fold greater than that required for inhibition of $\mathrm{PGI}_{2}$ synthesis. There was no obvious detachment of cells during the exposure period.

Although these cytotoxic concentrations of menadione have been shown to cause generation of reactive oxygen metabolites in endothelial cells (25), it is not known whether

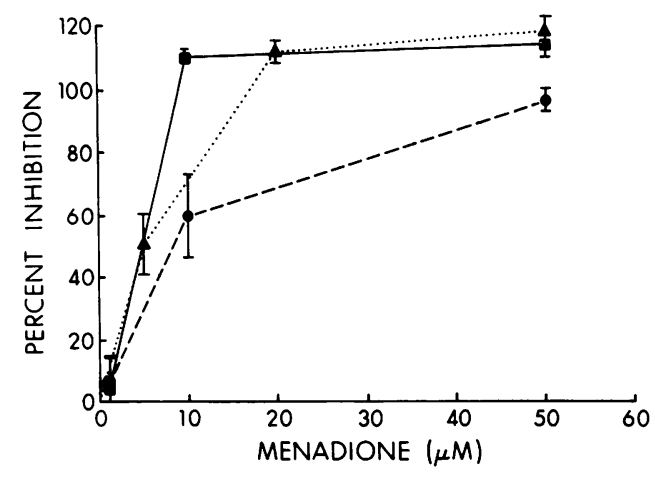

Figure 1. Menadione-induced inhibition of $\mathrm{PGI}_{2}$ synthesis. Endothelial cell monolayers were exposed to increasing concentrations of menadione for $10(\bullet \cdots-\bullet), 15(4 \ldots \ldots \downarrow)$, or $30(\bullet-\bullet) \mathrm{min}$, before rinsing. Prostaglandin synthetic capacity was tested by incubating the cells with $20 \mu \mathrm{M}$ arachidonic acid for $3 \mathrm{~min}$ and measuring the amount of $\mathrm{PGI}_{2}$ released into the buffer as described in Methods. This production in non-menadione-treated cells after addition of arachidonate was $122 \pm 20 \mathrm{ng} /$ flask above the basal production of $22.5 \pm 5.4 \mathrm{ng} /$ flask. Data are presented as the percentage of the total capacity of nontreated cells to produce prostaglandins. Each point represents the mean $\pm \mathrm{SD}, n=3$.

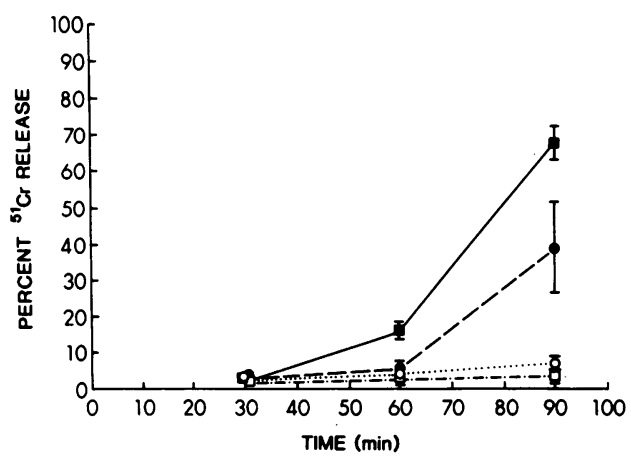

Figure 2. Time course of menadione-induced ${ }^{51} \mathrm{Cr}$ release. Cells were prelabeled with ${ }^{51} \mathrm{Cr}$ and rinsed as described in Methods. Release of label was followed with time from nontreated cells $(0 \cdots \cdots)$ or cells treated with $2 \mathrm{mM} \mathrm{H}_{2} \mathrm{O}_{2}(\bullet \ldots \bullet), 0.1 \mathrm{mM}$ menadione $(\square-\cdot-\bullet$ ), or $1 \mathrm{mM}$ menadione $(\square-)$ ) at $t=0$. Data are presented as the percentage of label relative to the total releasable ${ }^{51} \mathrm{Cr}$ within the monolayer and represent mean \pm SD of groups of four flasks of cells. At $60 \mathrm{~min}, 1 \mathrm{mM}$ menadione-treated flasks released significantly more ${ }^{51} \mathrm{Cr}$ than controls $(P<0.01)$; no other differences seen. At 90 min both $1 \mathrm{mM}$ menadione and $2 \mathrm{mM} \mathrm{H}_{2} \mathrm{O}_{2}$-treated flasks released significantly more ${ }^{51} \mathrm{Cr}$ than controls $(P<0.01)$ or 0.1 $\mathrm{mM}$ menadione-treated flasks which were not different from controls.

much lower, sublethal doses have the same effect. We examined this possibility by measuring oxygen consumption by monolayers of cells grown on beads. As shown in Fig. 3, the basal rate of $\mathrm{O}_{2}$ consumption $(3.43 \pm 1.71 \mathrm{nmol} / \mathrm{min}$ per $\mathrm{mg}$ protein) was increased 10-fold after addition of $20 \mu \mathrm{M}$ menadione $(34.8 \pm 5.4 \mathrm{nmol} / \mathrm{min}$ per $\mathrm{mg}$ protein). Addition of $130 \mathrm{U}$ of catalase resulted in a release of $\mathrm{O}_{2}$ into the system followed by a decrease in the rate of consumption to half the menadione-induced rate $(14.6 \pm 7.5 \mathrm{nmol} / \mathrm{min}$ per $\mathrm{mg}$ protein $)$. This effect of catalase could be explained by liberation of $\mathrm{O}_{2}$ from $\mathrm{H}_{2} \mathrm{O}_{2}$ accumulated in the buffer and equilibration to a rate governed by the stoichiometry of the reaction: $2 \mathrm{H}_{2} \mathrm{O}_{2} \rightarrow 2 \mathrm{H}_{2} \mathrm{O}$ $+\mathrm{O}_{2}(25,31)$. Menadione-driven $\mathrm{O}_{2}$ consumption was not inhibited by $1 \mathrm{mM} \mathrm{KCN}$ or by $2 \mu \mathrm{M}$ rotenone, demonstrating that the increase was not dependent on mitochondrial respira-

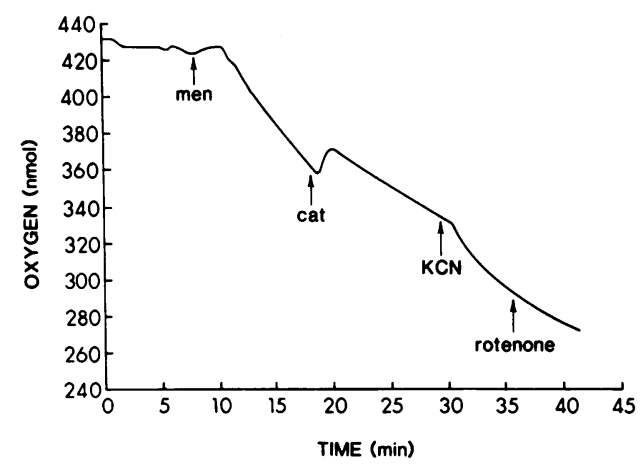

Figure 3. Oxygen consumption by endothelial cells grown on cytodex beads. Cells were cultured as described in Methods and loaded into a $2.8-\mathrm{ml}$ stirred chamber, which was maintained at $37^{\circ} \mathrm{C}$. Oxygen consumption was measured with a Clark electrode fitted into the chamber. At the designated times, menadione $(20 \mu \mathrm{M})$, catalase (130 $\mathrm{U}), \mathrm{KCN}(1 \mathrm{mM})$, or rotenone $(2 \mu \mathrm{M})$ was added. The protein content was $0.327 \mathrm{mg}$. The data are representative of four separate experiments. 
tion $(21,22,30,31)$. The accelerated rate after addition of $\mathrm{KCN}$ probably reflects inhibition of endogenous catalase $(30,31)$.

Since menadione-induced oxygen consumption was slowed by addition of catalase, we decided to quantify the amount of $\mathrm{H}_{2} \mathrm{O}_{2}$ diffusing from monolayers of endothelial cells grown in $25-\mathrm{cm}^{2}$ flasks. The basal rate of $\mathrm{H}_{2} \mathrm{O}_{2}$ accumulation was below the detection limits of our assay conditions ( $<0.5 \mathrm{nmol} / 15 \mathrm{~min}$, Table I). Menadione caused a dose-dependent increase in $\mathrm{H}_{2} \mathrm{O}_{2}$ formation. Addition of $\mathrm{NaN}_{3}$ increased this drug-induced accumulation of $\mathrm{H}_{2} \mathrm{O}_{2}$ twofold. These data indicate that metabolism of menadione by endothelial cells leads to measurable $\mathrm{H}_{2} \mathrm{O}_{2}$ formation, although the accumulation of $\mathrm{H}_{2} \mathrm{O}_{2}$ in the buffer probably underestimates the total amount of $\mathrm{H}_{2} \mathrm{O}_{2}$ formed.

It has been suggested that menadione can induce the formation of reactive oxygen species in the extracellular media as the fully reduced menadione diffuses from the cell and reoxidizes to menadione in the media $(21,25)$. We have previously demonstrated that extracellular generation of $\mathrm{O}_{2}^{-}$or addition of $\mathrm{H}_{2} \mathrm{O}_{2}$ causes inhibition of endothelial cell prostaglandin synthesis (10). This inhibition can be completely prevented by addition of catalase to the media (10). To test whether menadione inhibited prostaglandin synthesis via extracellular generation of oxidants, we preincubated monolayers for $15 \mathrm{~min}$ with increasing concentrations of menadione in the presence and absence of superoxide dismutase and catalase. We observed no effect of these enzymes on menadione-induced inhibition of prostaglandin synthesis $(P<0.05)$. This indicates that extracellular generation of $\mathrm{H}_{2} \mathrm{O}_{2}$ is not the mechanism for menadione inhibition of $\mathrm{PGI}_{2}$ synthesis. Therefore, the actions of menadione must be dependent on intracellular generation of inhibitory species or the drug has a direct effect on the synthetic enzymes of the prostaglandin cascade.

To examine the direct effects of menadione on $\mathrm{PGH}_{2}$ synthase, we chose to use a preparation of ram seminal vesicle microsomes, which are enriched with the enzyme. Ibuprofen, a known inhibitor of $\mathrm{PGH}_{2}$ synthase, was used as a positive control in these experiments. Nontreated microsomes converted $14.0 \pm 1.9 \%$ and $31.2 \pm 2.3 \%$ of $\left[{ }^{3} \mathrm{H}\right]$ arachidonate to hydroxylated products and prostaglandins, respectively. Ibupro-

Table I. Accumulation of $\mathrm{H}_{2} \mathrm{O}_{2}$ after Addition of Menadione

\begin{tabular}{lc}
\multicolumn{1}{c}{ Treatment } & $\mathrm{H}_{2} \mathrm{O}_{2}$ \\
\hline & nmol/flask \\
Control & $\mathrm{ND}$ \\
$1 \mathrm{mM} \mathrm{NaN}$ & $\mathrm{ND}$ \\
$5 \mu \mathrm{M}$ menadione & $2.75 \pm 0.19$ \\
$5 \mu \mathrm{M}$ menadione $+\mathrm{NaN}_{3}$ & $5.11 \pm 0.56$ \\
$20 \mu \mathrm{M}$ menadione & $4.32 \pm 0.22$ \\
$20 \mu \mathrm{M}$ menadione $+\mathrm{NaN}_{3}$ & $8.41 \pm 0.81$ \\
\hline
\end{tabular}

Cells, in $25-\mathrm{cm}^{2}$ flasks, were rinsed and exposed for $15 \mathrm{~min}$ to menadione diluted in $2 \mathrm{ml}$ of buffer. The buffer was collected and assayed for $\mathrm{H}_{2} \mathrm{O}_{2}$ content. Data represent mean $\pm \mathrm{SD}, n=3$. ND designates values which were below the detection limits of the assay $(0.5 \mathrm{nmol}$ of $\mathrm{H}_{2} \mathrm{O}_{2}$ ). Treatment with $20 \mu \mathrm{M}$ menadione was different from treatment with $5 \mu \mathrm{M}$ menadione $(P<0.01)$. $\mathrm{NaN}_{3}$ significantly enhanced the effect of either treatment $(P<0.01)$. fen prevented this conversion of arachidonate as indicated by a decrease in ${ }^{3} \mathrm{H}$ products and an increase in radioactivity eluting as unconverted arachidonic acid compared to control (94.5 $\pm 0.5 \%$ vs. $55.2 \pm 2.1 \%)$. In contrast, preincubation of microsomes for $5 \mathrm{~min}$ with $20 \mu \mathrm{M}$ menadione did not alter the elution profile indicating that menadione has no direct effect on conversion of arachidonic acid. Thus menadione inhibits $\mathrm{PGI}_{2}$ synthesis indirectly suggesting that the drug is metabolized by the endothelial cell to create an inhibitory species.

In addition to examining the effects of quinones on the activity of $\mathrm{PGH}_{2}$ synthase, it is also important to investigate effects on $\mathrm{PGI}_{2}$ synthase activity as well. This is the second enzyme in the prostaglandin synthetic cascade which is known to be sensitive to oxidants $(18,32,33)$. We exposed monolayers to menadione for $15 \mathrm{~min}$ before addition of $\mathrm{PGH}_{2}$, the substrate for $\mathrm{PGI}_{2}$ synthase. As shown in Fig. 4, $5 \mu \mathrm{M}$ menadione caused a $40 \%$ decrease in conversion of $\mathrm{PGH}_{2}$ to $\mathrm{PGI}_{2}$. There was no further inhibition observed in monolayers treated with $20 \mu \mathrm{M}$ of the drug. However, this effect on $\mathrm{PGI}_{2}$ synthase can only partially account for the inhibition of $\mathrm{PGI}_{2}$ synthesis from arachidonic acid.

We observed inhibition of arachidonic acid conversion at concentrations of menadione (Fig. 1) which have previously been shown to increase $\mathrm{Ca}^{2+}$ ionophore-stimulated release of $\mathrm{PGI}_{2}$ (34). It is possible that menadione leads to loss of $\mathrm{PGH}_{2}$ synthase activity by increasing the availability of free arachidonate. Metabolism of this arachidonate to $\mathrm{PGI}_{2}$ during the exposure period might cause autoinhibition of the enzyme. Therefore, we examined the effects of menadione on stimulated arachidonic acid release from endothelial cells prelabeled with $\left[{ }^{3} \mathrm{H}\right]$ arachidonic acid for $18 \mathrm{~h}$. As shown in Fig. $5 a$, pretreatment with menadione $(20 \mu \mathrm{M})$ for $15 \mathrm{~min}$ did not affect either basal or A23187-stimulated release of label. We also examined the effect of menadione on receptor-mediated release. In these experiments, there was also no alteration of basal release, nor was there an effect on release stimulated by the agonist, bradykinin (Fig. 5 b). Finally, to examine the effect of menadione on incorporation of arachidonic acid, we pretreated monolayers for $15 \mathrm{~min}$ with $20 \mu \mathrm{M}$ of the drug before adding $1.26 \mu \mathrm{Ci}$ of $\left[{ }^{3} \mathrm{H}\right.$ ]arachidonic acid. $200 \mu$ l of buffer were sampled at 5, 30, 45, and $60 \mathrm{~min}$ to determine amount of unincorporated radioactivity. There was no difference in the rate of incorporation of label into nontreated and treated cells

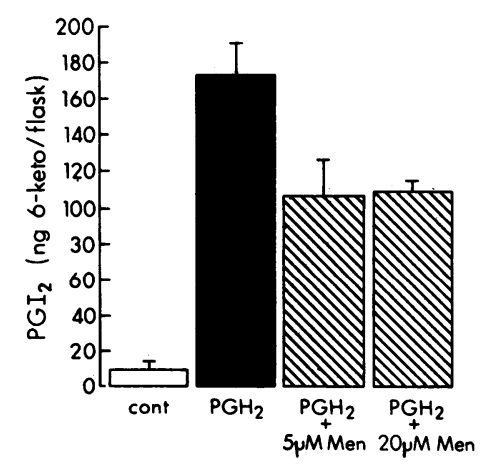

Figure 4. Menadione-induced inhibition of endothelial $\mathbf{P G I}_{2}$ synthase. Monolayers were exposed to menadione for $15 \mathrm{~min}$. After rinsing, buffer containing $5 \mu \mathrm{g} / \mathrm{ml} \mathrm{PGH}{ }_{2}$ was added and the cells were incubated for an additional $5 \mathrm{~min}$. The buffer was then removed and assayed for $\mathrm{PGI}_{2}$. Data are mean $\pm \mathrm{SD}$, $n=3$. All flasks incubated with $\mathrm{PGH}_{2}$ produced significantly more $\mathrm{PGI}_{2}$ than controls $(P<0.01)$. Menadione at both doses inhibited conversion $(P<0.05)$. 

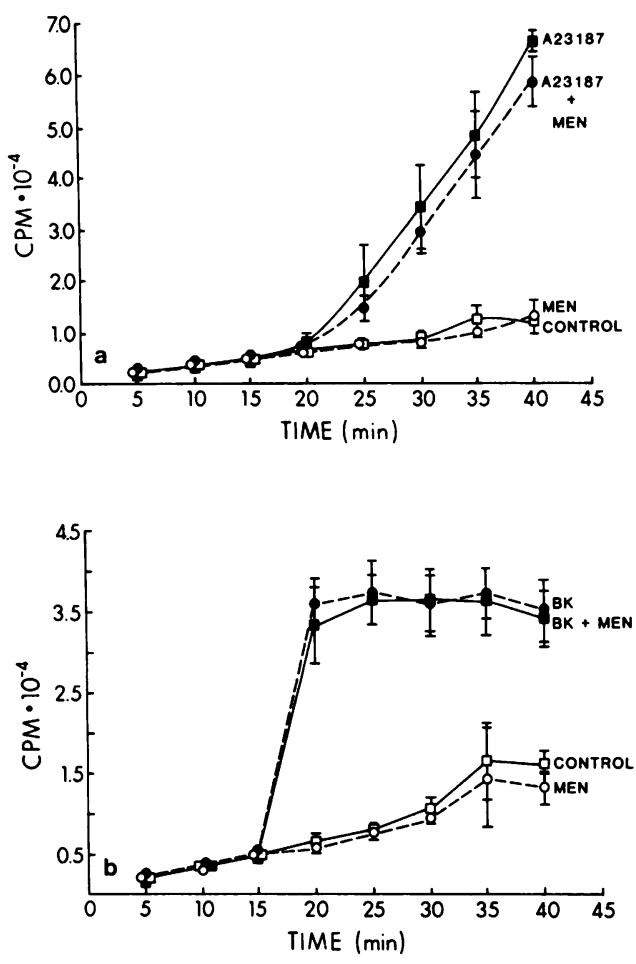

Figure 5. Effect of menadione on (a) A23187- or (b) bradykinin $(B K)$-stimulated arachidonate release. Cells, prelabeled for $18 \mathrm{~h}$ with $\left[{ }^{3} \mathrm{H}\right]$ arachidonate, were exposed to menadione $(20 \mu \mathrm{M}, 15 \mathrm{~min})$. After rinsing, release of label was followed by sampling buffer every 5 min. At 15 or $20 \mathrm{~min}, \mathrm{BK}(100 \mathrm{ng} / \mathrm{ml})$ or A23187 $(1 \mu \mathrm{M})$, respectively, was added. Data are mean $\pm \mathrm{SD}, n=4$. Menadione did not alter release of label from either control, A23187-, or BK-stimulated cells. Both A23187- and BK-treated cells released significantly more label than controls at all time points after addition of the agonist $(P$ $<0.01)$

$(0.734 \pm 0.008$ vs. $0.736 \pm 0.010 \mu \mathrm{Ci} /$ flask per $\mathrm{h}$ respectively, $n=4)$.

We have previously demonstrated that sublethal concentrations of $\mathrm{H}_{2} \mathrm{O}_{2}$ cause irreversible inactivation of $\mathrm{PGH}_{2}$ synthase, and that new enzyme must be synthesized in order to regain prostaglandin synthetic capacity in the endothelial cell (11). If menadione-induced inhibition of prostaglandin synthesis is also the result of irreversible enzyme inactivation and if, as shown in Fig. 2, this inhibition occurs at sublethal concentrations of menadione, then the monolayers should be able to recover after exposure. To test this hypothesis, we exposed monolayers to $20 \mu \mathrm{M}$ menadione for $15 \mathrm{~min}$. The cells were then washed and incubated for varying periods of time in medium 199 plus $1 \%$ FCS before testing the capacity to produce prostaglandins. As shown above, this dose of menadione inhibited the conversion of exogenous arachidonic acid to $\mathrm{PGI}_{2}$. A full $6 \mathrm{~h}$ was required before prostaglandin synthetic capacity returned to normal (Fig. 6). This recovery time course is identical to that we have reported for the recovery of $\mathrm{PGH}_{2}$ synthase following inhibition by $\mathrm{H}_{2} \mathrm{O}_{2}$ (11).

\section{Discussion}

The results of this investigation demonstrate that menadione causes irreversible inhibition of endothelial prostaglandin synthesis. This inhibition is both concentration- and time-related,

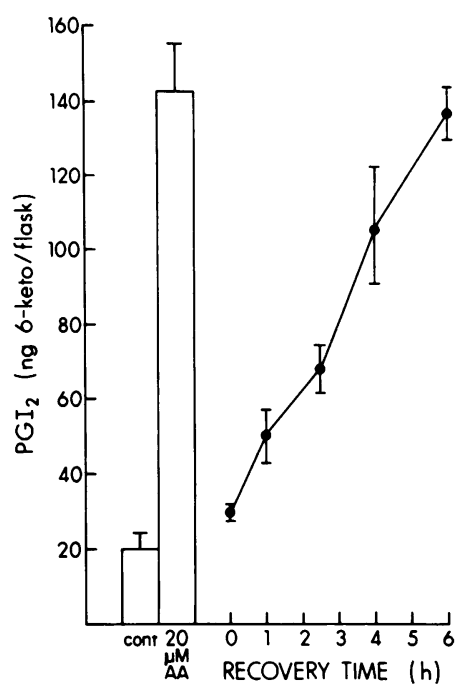

Figure 6. Recovery of endothelial prostaglandin synthesis inhibited by menadione. Cells were exposed to menadione $(20 \mu \mathrm{M})$ for $15 \mathrm{~min}$, rinsed, and incubated for varying times with medium 199 containing $1 \%$ FCS. The culture media was removed and the prostaglandin synthetic capacity was tested. Bars () represent production in nontreated cells, while closed circles $(\bullet)$ represent production in menadionetreated cells. Data represent mean $\pm \mathrm{SEM}, n=6$.

yet occurs at lower concentrations and with a shorter time course than menadione-induced release of ${ }^{51} \mathrm{Cr}$. Thus menadione-induced loss of endothelial cell function greatly precedes loss of cell integrity.

The primary mechanism for menadione cytotoxicity is formation of reactive oxygen species. Rosen and Freeman (25) demonstrated that menadione, in high concentrations, induced formation of $\mathrm{O}_{2}^{-}$in endothelial cells. These studies demonstrated that $100 \mu \mathrm{M}$ menadione increased both intracellular and extracellular production of $\mathrm{O}_{2}^{-}$and subsequent formation of $\mathrm{H}_{2} \mathrm{O}_{2}$. Our present data demonstrate that menadione increases endothelial oxygen consumption by 10 -fold at a dose five times lower than that used previously. That this consumption represents partial reduction of molecular oxygen leading to the formation of $\mathrm{H}_{2} \mathrm{O}_{2}$ is supported by several findings: (a) accumulation of $\mathrm{H}_{2} \mathrm{O}_{2}$ is dependent on menadione concentration; $(b)$ addition of extracellular catalase slows the rate of oxygen consumption; (c) $\mathrm{H}_{2} \mathrm{O}_{2}$ accumulation is augmented by addition of $\mathrm{NaN}_{3}$. The most likely mechanism for the effect of $\mathrm{NaN}_{3}$ is inhibition of intracellular catalase (30, 31); although $\mathrm{NaN}_{3}$ may act to inhibit mitochondrial respiration, thus providing more reducing equivalents to drive menadione redox cycling. However, since endothelial cells contain few mitochondria (35), this contribution of reducing equivalents would be minimal.

The exact mechanism for menadione-dependent $\mathrm{H}_{2} \mathrm{O}_{2}$ formation in endothelial cells has not been investigated, but it is probably qualitatively similar to mechanisms observed in other cell types. In the rat hepatocyte, menadione has been shown to be reduced by enzymes in the mitochondria and endoplasmic reticulum to form the semiquinone (21-24). This radical is a strong nucleophile and can react with a variety of intracellular constituents including membrane proteins, DNA, $\mathrm{GSH}$, and $\mathrm{O}_{2}(23,24)$. The semiquinone is reoxidized to menadione, causing generation of $\mathrm{O}_{2}^{-}(21-24)$. A continued recycling of the semiquinone to the quinone and detoxification of the oxygen metabolites produced leads to depletion of reducing equivalents within the cell and cytotoxicity ensues $(23,36)$. Although this pathway appears universal, cells differ in their sensitivities to menadione (23). These differences are quite pronounced and form the basis for use of menadione as an antineoplastic agent $(37,38)$ or to sensitize tumor cells to var- 
ious forms of oxidative anticancer therapies $(26,27)$. It is interesting that we observe inhibition of endothelial cell function within the range of menadione concentrations found to be effective in killing a variety of tumor cells in vitro $(37,38)$, but loss of endothelial cell viability occurred at a 200 -fold higher concentration.

Differential sensitivities of various cell types to the effects of menadione may be due to differences in number of mitochondria (23), in the relative contribution of extramitochondrial metabolism of the drug (22), in the intracellular content of NADPH (23), or in the cellular content of GSH $(23,36)$. Jones et al. (23) proposed that renal epithelial cells were more sensitive to menadione cytotoxicity than hepatocytes, because menadione cytotoxicity is dependent on mitochondrial metabolism of the drug and the renal cells contain more mitochondria. This would predict that endothelial cells would be less sensitive than hepatocytes to menadione effects, since they contain few mitochondria (35). However, our data indicate that the dose relationship for menadione-induced cytotoxicity in the endothelial cell is similar to those observed in hepatocytes $(21,39)$. For menadione to have a similar potency in both cell types, endothelial cells must have a great capacity for microsomal metabolism of the drug. This is supported by the fact that endothelial cells are predominately glycolytic and are capable of increasing their level of NADPH many fold upon demand (35). Such an increase in NADPH could augment deleterious univalent reduction of menadione by the microsomal electron transport systems.

The time course and dose dependence of menadione-induced $\mathrm{H}_{2} \mathrm{O}_{2}$ formation are consistent with menadione-induced inhibition of $\mathrm{PGI}_{2}$ synthesis, supporting our hypothesis that it is $\mathrm{H}_{2} \mathrm{O}_{2}$ which mediates this inhibition. We have previously demonstrated that sublethal doses of $\mathrm{H}_{2} \mathrm{O}_{2}$ inhibit endothelial cell prostaglandin synthesis by irreversibly inactivating the $\mathrm{PGH}_{2}$ synthase $(10,11)$. In the present study, menadione was shown to cause a similar inhibition although this drug has a minor effect on the $\mathbf{P G I}_{2}$ synthase as well. $\mathbf{P G I}_{2}$ synthase is known to be sensitive to lipid hydroperoxides $(18,32,33)$, but menadione-induced formation of these species is unlikely, since menadione is known to prevent propagation of lipid peroxides $(40,41)$. Since we have previously demonstrated that endothelial cell $\mathrm{PGI}_{2}$ synthase is not affected by $\mathrm{H}_{2} \mathrm{O}_{2}$, it is likely that menadione, or the semiquinone, has a direct effect on this enzyme.

Nolan and Eling (34) demonstrated that menadione had a biphasic effect on A23187-stimulated $\mathrm{PGI}_{2}$ synthesis in endothelial cells, with concentrations of $>1 \mu \mathrm{M}$ augmenting production. The mechanism for this stimulation was not described, although an analogue of menadione, vitamin $K_{1}$, was shown to attenuate $\mathbf{P G I}_{2}$ synthesis by preventing release of endogenous arachidonate. Since the stimulatory effect of menadione was not characterized, it is difficult to explain the difference between the findings of this previous study and our present data. However, since we did not find an effect of menadione on either bradykinin- or A23187-stimulated release, we conclude that the inhibitory effects of menadione on endothelial prostaglandin production are limited to the synthetic enzymes of the cascade.

Consistent with our previous findings (11), we demonstrated that, although $\mathrm{PGH}_{2}$ synthase is irreversibly inactivated after treatment with menadione, the endothelial cell can recover lost capacity to produce prostaglandins. In $\mathrm{H}_{2} \mathrm{O}_{2}$-treated endothelial cells, this recovery was shown to be dependent on synthesis of both new mRNA and protein (11). In a recent study, we found that this RNA synthesis occurs with a half-life of $3 \mathrm{~h}$, while the half-life for new protein synthesis was only 1.3 $h(42)$. These rates are consistent with the time required for full recovery of lost prostaglandin synthetic capacity.

In conclusion, these data demonstrate that sublethal concentrations of menadione cause a rapid, irreversible inactivation of endothelial cell prostaglandin production. This inhibition appears to be dependent on formation of reactive oxygen species after metabolism of the drug by the endothelial cell. Consistent with our previous findings $(10,11)$, this oxidantmediated inhibition is limited to the synthetic enzymes of the prostaglandin cascade and the activity of these enzymes can be restored by synthesizing new enzyme. These data indicate that the effects of menadione on vascular cell function can greatly proceed the cytotoxic effects of the drug.

\section{Acknowledgments}

A. Barchowsky was supported by NIEHS training grant T32-E507031. The authors wish to thank Lori Tripp for her excellent help in preparing this manuscript.

This work was supported by grants AG- 02868 and HL-31992 from the National Institutes of Health and by a grant from the Burroughs Wellcome Fund.

\section{References}

1. Suttorp, N., and L. M. Simon. 1982. Lung cell oxidant injury. Enhancement of polymorphonuclear leukocyte-mediated cytotoxicity in lung cells exposed to sustained in vitro hyperoxia. J. Clin. Invest. 70:342-350.

2. Tate, R. M., and J. E. Repine. 1983. Neutrophils and adult respiratory distress syndrome. Am. Rev. Respir. Dis. 128:552-559.

3. Autor, A. P., A. C. Bonham, and R. L. Theis. 1984. Toxicity of oxygen radicals in cultured pulmonary endothelial cells. J. Toxicol. Environ. Health. 13:387-395.

4. Sjostrom, K., and J. D. Crapo. 1983. Structural and biochemical adaptive changes in rat lungs after exposure to hypoxia. Lab. Invest. 48:68-79.

5. Orr, F. W., and D. J. A. Warner. 1987. Effects of neutrophilmediated pulmonary injury on the localization of circulating Walkers carcinosarcoma cells. Invasion Metastasis. 7:183-196.

6. Reidy, M. A., and S. M. Schwartz. 1983. Endothelial injury and regeneration. IV. Endotoxin: a non-denuding injury to aortic endothelium. Lab. Invest. 48:25-34.

7. Brigham, K. L., and B. Meyrick. 1986. Endotoxin and lung injury. Am. Rev. Respir. Dis. 133:913-927.

8. Lazo, J. S. 1986. Endothelial injury caused by antineoplastic agents. Biochem. Pharmacol. 35:1919-1923.

9. Adamson, I. Y. R. 1984. Drug-induced pulmonary fibrosis. Environ. Health. Perspect. 55:25-36.

10. Whorton, A. R., M. E. Montgomery, and R. S. Kent. 1985. Effect of hydrogen peroxide on prostaglandin production and cellular integrity in cultured porcine aortic endothelial cells. J. Clin. Invest. 76:295-302.

11. Barchowsky, A., R. S. Kent, and A. R. Whorton. 1987. Recovery of porcine aortic endothelial cell prostaglandin synthesis following inhibition by sublethal concentrations of hydrogen peroxide. Biochim. Biophys. Acta. 927:372-381.

12. Gryglewski, R. J., and S. Moncada. 1987. Secretory function of vascular endothelium. Adv. Prostaglandin Thromboxane Leukotriene Res. 17:397-404.

13. Simpson, P. J., and B. R. Lucchesi. 1987. Free radicals and 
myocardial ischemia and reperfusion injury. J. Lab. Clin. Med. 110:13-30.

14. Czervionke, R. C., J. B. Smith, G. L. Fry, J. C. Hoak, and D. C. Haycraft. 1979. Inhibition of prostacyclin by treatment of endothelium with aspirin: correlation with platelet adherence. J. Clin. Invest. 63:1089-1092.

15. Fantone, J. C., and D. A. Kinnes. 1983. Prostaglandin $E_{1}$ and prostaglandin $\mathrm{I}_{2}$ modulation of superoxide production by neutrophils. Biochem. Biophys. Res. Commun. 113:506-512.

16. Kulmacz, R. J. 1986. Prostaglandin H synthase and hydroperoxides: peroxidase reaction and inactivation. Arch. Biochem. Biophys. 249:273-285.

17. Marshall, P. J., R. J. Kulmacz, and W. E. M. Lands. 1987. Constraints on prostaglandin biosynthesis in tissues. J. Biol. Chem. 262:3510-3517.

18. Kent, R. S., S. L. Deidrich, and A. R. Whorton. 1983. Regulation of vascular prostaglandin synthesis by metabolites of arachidonic acid in perfused rabbit aorta. J. Clin. Invest. 72:455-465.

19. Brotherton, A. F., and J. C. Hoak. 1983. Prostaglandin biosynthesis in cultured vascular endothelium is limited by deactivation of cyclooxygenase. J. Clin. Invest. 72:1255-1261.

20. Madden, M. C., T. E. Eling, and M. Friedman. 1987. Ozone inhibits endothelial cell cyclooxygenase activity through formation of hydrogen peroxide. Prostaglandins. 34:445-463.

21. Thor, H., M. T. Smith, P. Hartzell, G. Bellomo, S. A. Jewell, and S. Orrenius. 1982. The metabolism of menadione (2-methyl-1,4napthoquinone) by isolated hepatocytes. J. Biol. Chem. 257:1241912425.

22. de Groot, H., T. Noll, and H. Sies. 1985. Oxygen dependence and subcellular partitioning of hepatic menadione-mediated oxygen uptake. Studies with isolated hepatocytes, mitochondria and microsomes from rat liver in an oxystat system. Arch. Biochem. Biophys. 243:556-562.

23. Jones, T. W., H. Thor, and S. Orrenius. 1986. Cellular defense mechanisms against toxic substances. Arch. Toxicol. Suppl. 9:259271.

24. Frei, B., K. H. Winterhalter, and C. Richter. 1986. Menadione-(2-methyl-1,1,4-napthoquinone)-dependent enzymatic redox cycling and calcium release by mitochondria. Biochemistry. 25:44384443.

25. Rosen, G. M., and B. A. Freeman. 1984. Detection of superoxide generated by endothelial cells. Proc. Natl. Acad. Sci. USA. 81:7269-7273.

26. Whorton, A. R., S. L. Young, J. L. Data, A. Barchowsky, and R. S. Kent. 1982. Mechanism of bradykinin-stimulated prostacyclin synthesis in porcine aortic endothelial cells. Biochim. Biophys. Acta. 712:79-87.

27. Thurman, R. G., H. G. Ley, and R. Scholz. 1972. Hepatic microsomal ethanol oxidation. Hydrogen peroxide and the role of catalase. Eur. J. Biochem. 25:420-430.
28. Bergmeyer, H. O. 1955. Zur messung von Katalase-aktivitäten. Biochem. Z. 327:255-258.

29. McCord, J. M., and I. Fridovich. 1965. Superoxide dismutase. An enzymatic function for erythrocuprein (hemocuprein). J. Biol. Chem. 244:6049-6055.

30. Thayer, W. S. 1977. Adriamycin stimulated superoxide formation in submitochondrial particles. Chem. Biol. Interact. 19:265-278.

31. Hassan, H. M., and I. Fridovich. 1979. Intracellular production of superoxide radical and of hydrogen peroxide by redox activity compounds. Arch. Biochem. Biophys. 196:385-395.

32. Demopulos, H. B., E. S. Flam, and D. D. Pietromyro. 1980. The free radical pathology and the microcirculation in the major central nervous system disorders. Acta Physiol. Scand. 492:91-119.

33. Salmon, J. A., D. R. Smith, R. J. Flower, S. Moncoda, and J. R. Vane. 1978. Further studies on the enzymatic conversion of prostaglandin endoperoxide into prostacyclin by porcine aorta microsomes. Biochim. Biophys. Acta. 523:250-262.

34. Nolan, R. D., and T. E. Eling. 1986. Inhibition of prostacyclin synthesis in cultured bovine aortic cells by vitamin $\mathrm{K}_{1}$. Biochem. Pharmacol. 35:4273-4281.

35. Dobrina, A., and F. Rossi. 1983. Metabolic properties of freshly isolated bovine endothelial cells. Biochim. Biophys. Acta. 762:295301.

36. Bellomo, G., F. Mirabelli, D. DiMonte, P. Richelmi, H. Thor, C. Orrenious, and S. Orrenius. 1987. Formation and reduction of glutathione-protein mixed disulfides during oxidative stress. A study with isolated hepatocytes and menadione (2-methyl-1,4-napthoquinone). Biochem. Pharmacol. 36:1313-1320.

37. Chlebowski, R. T., S. A. Akman, and J. B. Block. 1985. Vitamin $\mathrm{K}$ in the treatment of cancer. Cancer Treat. Rev. 12:49-63.

38. Su, Y-Z., T. E. Duarte, P. L. Dill, and L. M. Weisenthal. 1987. Selective enhancement by menadiol of in vivo drug activity in human lymphatic neoplasms. Cancer Treat. Rep. 71:619-625.

39. DiMonte, D., G. Bellomo, H. Thor, P. Nicoteva, and S. Orrenius. 1984. Menadione-induced cytotoxicity is associated with protein thiol oxidation and alteration in intracellular $\mathrm{Ca}^{2+}$ homeostasis. Arch. Biochem. Biophys. 235:343-350.

40. Talcott, R. E., M. T. Smith, and D. D. Giannini. 1985. Inhibition of microsomal lipid peroxidation by napthoquinones: structureactivity relationships and possible mechanisms of action. Arch. Biochem. Biophys. 241:88-94.

41. Younes, M., S. Cornelius, and C. P. Siegers. 1985. Fe ${ }^{2+}$-supported in vivo lipid peroxidation induced by compounds undergoing redox cycling. Chem. Biol. Interact. 54:97-103.

42. Whorton, A. R., Z. Mirza, A. Barchowsky, and B. J. Buckley. 1988. Protein kinase $C$ regulation of arachidonate release and metabolism in aortic endothelial cells. FASEB (Fed. Am. Soc. Exp. Biol.) J. 2:A1188. (Abstr.) 